\title{
Membentuk Karakter Anak Usia Dini melalui Permainan Tradisional
}

\author{
Sardiah Srikandi ${ }^{1}$, I Made Suardana ${ }^{2}$, Sulthoni $^{3}$ \\ ${ }^{1}$ Pendidikan Anak Usia Dini-Universitas Negeri Malang \\ ${ }^{2}$ Keguruan Sekolah Dasar dan Prasekolah-Universitas Negeri Malang \\ ${ }^{3}$ Teknologi Pendidikan-Universitas Negeri Malang
}

\section{INFO ARTIKEL}

\section{Riwayat Artikel:}

Diterima: 10-06-2020

Disetujui: 22-12-2020

\author{
Kata kunci: \\ traditional games; \\ early childhood: \\ characters; \\ permainan tradisional; \\ anak usia dini; \\ karakter
}

\author{
Alamat Korespondensi: \\ Sardiah Srikandi \\ Pendidikan Anak Usia Dini \\ Universitas Negeri Malang \\ Jalan Semarang 5 Malang \\ E-mail: diahmarbun1@gmail.com
}

\begin{abstract}
ABSTRAK
Abstract: Forming characters in early childhood is very important to do through various ways, one of which is to carry out traditional games. The focus of this research is how to shape the character of early childhood through the traditional play of Engklek and Umpet Plots in PAUD Omah Bocah An-Na'afi Malang, East Java. This study uses qualitative methods, this type of research is descriptive research that describes the actual events that are supported by data in the form of observations, and interviews. The results of this study indicate that the traditional play activities of the Engklek and Umpet Plots are carried out for 30 minutes from 10.30 to 11.05 , and the activities are carried out routinely from Monday to Thursday. The traditional play activities of Engklek and Umpet Plots can form early childhood characters starting from honesty, responsibility, discipline, mutual cooperation, self-reliance, and religious character.

Abstrak: Membentuk karakter pada anak usia dini sangat penting untuk dilakukan melalui berbagai cara, salah satunya adalah dengan melaksanakan permainan tradisional. Fokus penelitian ini adalah bagaimana membentuk karakter anak usia dini melalui permainan tradisional Engklek dan Petak Umpet di PAUD Omah Bocah AnNa'afi Malang Jawa Timur. Penelitian ini menggunakan metode kualitatif. Jenis penelitian ini yaitu penelitian deskriptif yang menggambarkan kejadian yang sebernarnya yang didukung oleh data berupa observasi dan wawancara. Hasil penelitian ini menunjukkan bahwa kegiatan permainan tradisional Engklek dan Petak Umpet yang dilaksanakan selama 30 menit dari jam 10.30 sampai dengan 11.05 , dan kegiatannya dilakukan secara rutin pada hari Senin-Kamis. Kegiatan permainan tradisional Engklek dan Petak Umpet ini dapat membentuk karakter anak usia dini mulai dari karakter kejujuran, karakter tanggungjawab, karakter disiplin, karakter gotong-royong, karakter mandiri, dan karakter religius.
\end{abstract}

Taman kanak-kanak merupakan suatu pendidikan yang melakukan pembelajaran dengan bermain karena bermain merupakan dunia anak. Sebagaiamana pernyataan (Merpina, Marmawi, \& Yuline, 2014) dalam pendidikan anak usia dini suatu pembelajaran dilakukan dengan bermain dan sambil belajar agar anak dapat mengekspresikan dirinya. Sama halnya yang dikatakan oleh (Widodo \& Lumintuarso, 2017) yang mengatakan bahwa bermain merupakan suatu aktivitas yang harus di wajibkan pada anak untuk menjadikan dirinya lebih senang agar terhindar dari stress pada anak sehingga anak lebih bebas untuk berinteraksi dengan teman sebayanya. Namun, untuk saat ini dapat dilihat pada anak saat bermaian kebanyakan menggunakan alat-alat elektronik yang dapat merusak mata dan otak. Sebagaiamana (Ambaryani, Yustinus, \& Sujana, 2014) menyatakan bahwa permainan elektronik dapat menyebabkan dampak negatif pada anak salah satunya terjadi permusuhan dan perkelahian. Pernyataan sama juga dinyatakan oleh (Anggita, 2019) anak yang cenderung menggunakan elektronik untuk bermain, seperti menonton dan game online kemungkinan akan berakibat fatal terjadinya obesitas pada anak dan kurangnya pergerakan badan pada tubuh anak. Permainan Tradisional merupakan suatu kegiatan yang telah ada pada zaman dahulu sampai sekarang. Permainan tradisional merupakan suatu permainan yang sudah ada sejaak zaman dulu dan memilki dampak yang baik pada anak dalam hal bersosialisai, kerjasama dan berinteraksi. Menurut (Sibarani, 2018) permainan tradisional merangsang rasa empati, kerjasama, saling peduli, empati, saling menghargai dan juga lebih banyak berinteraksi dalam bersosial antara temannya.

Menurut (Aghlara \& Tamjid, 2011) permainan tradisional merupakan suatu kegiatan yang menyerupai olahraga yang dapat menjadikan hiburan dalam diri sendiri yang dilakukan untuk mencapai suatu hal yang telah disesuaikan bersama dengan teman sepermainan. Permainan tradisional banyak sekali nilai-nilai yang dapat ditimbulkan saat permainan dilakukan 
diantaranya nilai kebebasan, tanggungjawab, dan saling membantu. Menurut (Lusiana, 2012) dalam permainan tradisional terdapat nilai-nilai kebudayaan yang memainkan permainan tersebut, yaitu nilai kesenangan, kebebasan, demokratis, kejujuran, dan rasa tanggungjawab. Permainan tradisional hanya menggunakan alat-alat seadanya, seperti kayu, batu-batuan, atau barang bekas yang mudah didapat di lingkungan sekitar tanpa mengeluarkan biaya dan hanya mengumpulkan beberapa teman untuk dapat memainkan permainan tersebut. Menurut (Suhono \& Sari, 2017) permainan tradisional diwariskan unntuk masyrakat sekitar terutama bagi anak-anak usia 4-7 tahun. Sama halnya yang dikatakan oleh (Eichberg, 2005) permainan tradisional merupakan suatu warisan sejarah yang harus di terapkan pada dunia pendidikan.

Pelaksanakan permainan tradisional dapat membentuk karakter pada seseorang yang memainkannya yang tampak terlihat pada perilaku atau tingkah laku sehari-hari sehingga dalam hal ini sangat baik dilakukan pada anak sejak ini karena awal yang baik untuk membentuk karakter di mulai dari anak usia dini. Karakter merupakan suatu sikap dan tingkah laku yang baik. Menurut (Rahmawati \& Harsono, 2018) karakter merupakan nilai dasar yang harus dibentuk pada seseorang yang pengaruhnya dapat diperoleh dari lingkungan dan juga keturunan. Hal ini dapat dijelakan oleh (Nur, 2013) yang mengatakan bahwa permainan tradisional banyak memiliki peran yang sangat penting untuk membentuk karakter anak yang seharusnya ditanamkan pada anak usia dini sehingga pada permainan tersebut anak lebih terbiasa untuk melakukannya dan lupa akan permainan modern seperti HP, Game Online, dan Gadget yang semakin canggih seperti sekarang yang telah kita lihat. Maka untuk itu sebagai pendidik atau halnya juga orangtua dirumah harus lebih memperkenalkan dan membiasakan kepada anak dalam permainan tradisional yang telah ada sejak dahulu. Menurut (Iswinarti, Ekowarni, MG, \& Hidayat, 2016) permainan tradisional anak akan tampak pada sosialnya saat berinteraksi dengan teman-temannya dan juga akan tampak dapa anak yang tidak sering melakukan permainan tradisional. Menurut (Rochmani, 2016) permainan tradisional merupakan suatu sarana dan prasarana yang dapat mendorong salah satu pembelajaran pada anak usia dini yang memiliki banyak keunikan didalamnya pada anak saat bermain yang juga dapat meningkatkan daya berpikir anak. Sejalan dengan pendapat (Suruh, 2013) menyatakan bahwa dalam bermain permainan tradisional dapat menyesuaikan sosial anak dengan orang yang ada di sekitarnya sehingga anak akan lebih mudah bersosialisasi dan belajar bersama dengan teman-temannya.

\section{METODE}

Pendekatan yang dilakukan dalam suatu penelitian ini adalah dengan melakukan pendekatan kualitatif. Jenis penelitian ini yaitu penelitian deskriptif yang menggambarkan kejadian yang sebernarnya yang didukung oleh data berupa observasi, wawancara, dan dokumentasi. Sebagaimana yang dikatakan oleh (Tarigan, 2013) bahwa penelitian deskriptif merupan suatu inti permasalahan yang dicari oleh peneliti yang mengambarkan suatu kejadian yang sebenarnya. Subjek penelitian ini adalah anak yang berusia 4-6 tahun dan kepala PAUD Omah Bocah An-Na'afi Malang Jawa Timur. Data di dapat dari hasil pengamatan dan wawancara dengan kepala PAUD. Lokasi penelitian ini berada di Jl. Perum Griyansantha Blok L PAUD Omah Bocah An-Na'afi.

Sumber data dalam penelitian ini menggunakan data dari Lofland (dalam Moleong, 2011), yaitu (1) kata-kata dan tindakan, (2) sumber tertulis, dan (3) foto. Dalam sumber data ada beberapa hal yang harus diperoleh dalam mencari suatu data, dimana hal tersebut dapat dicari untuk melengkapi penelitian yang dilakukan. Teknik pengumpulan diperoleh dengan observasi secara langsung dan melakukan wawancara. Sebagaimana yang dikatakan (Saputra, 2017) dalam teknik pengumpulan data bisa menggunakan secara observasi dapat dilakukan secara langsung dengan mengamati setiap perilaku yang diakukan, dokumentasi dimana dapat dilakukan dengan mencari data-data melalui internet, koran dan majalah lainnya serta studi literatur suatu cara yang digunakan untuk mendukung hasil penelitian dengan mencari di majalah, buku, dan jurnal lainnya. Pengecekan keabsahan data dilakukan untuk melihat keaslian data yang telah diperoleh dari tempat peneliti. pengecekan keabsahan data melalui kredibilitas dengan cara mengumpulkan data dengan situasi yang lebih kompleks dan mengungkapkan pola yang dianggap sukar, juga dapat menunjukkan bahwa data yang diperoleh benar dengan salah satunya menggunakan member check. Pengecekan keabsahan data dapat dilakukan secara rutin, yaitu (1) ketekunan melakukan pengamatan yang berarti dilakukan lebih konsisten dengan melihat situasi yang relevan pada masalah yang sedang dicari dan memfokuskannya secara nyata; (2) pemeriksaan secara diskusi untuk memeriksa keabsahan data untuk lebih benar lagi. Apabila data yang sudah disetujui dari informan maka data tersebut dikatakan valid. Selanjutnya, setelah data diperoleh peneliti dapat di tulis dengan bentuk laporan kualitatif deskriptif.

\section{HASIL}

Pelaksanaan permainan tradisional Engklek dan Petak Umpet untuk membentuk karakter terhadap anak usia dini adalah suatu cara yang dapat dilakukan untuk memberikan pembelajaran yang menarik dan menyenangkan. Sebagai langkah awal peneliti melakukan observasi pada tanggal 13-14 Januari 2020 dan diperoleh data dimana permainan tradisional Engklek dan Petak Umpet dilakukan di luar kelas dan bersama-sama dengan anak setiap hari Senin sampai Kamis. Permainan tradisional Engklek dan Petak Umpet dilakukan jika pembelajaran yang diterapkan guru telah selesai dan anak dianjurkan untuk melakukan permainan tradisional Engklek dan Petak Umpet.

Kegiatan permainan tradisional Engklek dan Petak Umpet dilakukan dari jam 10.30-11.00 WIB. Jadwal kegiatan permainan tradisional Englek dan Petak Umpet pada anak usia 4-6 tahun. Untuk anak TK A jika telah mendapat giliran bermain di luar maka mereka dapat melaksanakan suatu permainan tradisional Engklek dan juga Petak Umpet dan besoknya 
giliran anak TK B dalam melaksanakan permainan tradisional Engklek dan Petak Umpet tersebut. Fasilitas yang tersedia untuk melaksanakan kegiatan permainan tradisional Engklek dan Petak Umpet antara lain lapangan yang cukup luas untuk permainan tradisional petak umpet dan kadang anak-anak dapat melakukannya di halaman Masjid dekat dengan sekolah, untuk permainan tradisional angklek sudah ada gambar yang dicat membentuk permainan seperti angklek, namun permainan Engklek juga dilengkapi dengan kayu yang telah dibentuk, maka anak-anak dapat melakukannya sesuai dengan kesukaan mereka atau kesepakatan masing-masing antara guru PAUD dan anak-anak.

Permainan tradisional Engklek dan Petak Umpet dapat membentuk karakter pada anak dan memengaruhi karakternya. Hal tersebut dikarenakan permainan tradisional Engklek dapat membentuk karakter, seperti gotong royong dimana saling membereskan peralaatan setelah digunakan, mandiri saat mencari batu atau disebut kacu untuk bisa bermain, serta dapat membentuk karakter tanggungjawab dimana anak akan bertanggungjawab ketika kalah dalam permainan. Membentuk dan menanamkan karakter pada anak melalui permainan tradisional Engklek dan Petak Umpet dengan usia empat sampai enam tahun tentunya tidak mudah karena karakter dan cara yang dimiliki setiap masing-masing anak berbeda maka diperlukan suatu cara yang telah sesuai dengan karakteristik anak usia dini. Hal ini dikarenakan pada umumnya anak masih belum dapat mengatur posisinya sendiri, cenderung bercanda, dan saling mendorong. Namun, ketika saat memasuki permainan tradisional engklek dan petak umpet anak sudah mulai tenang, mulai mengikuti instruksi dari guru walaupun masih ada sebagian anak yang bercanda atau mengobrol dengan teman di sampingnya.

Cara dan aturan permainan tradisional yang dilakukan anak usia dini di PAUD Omah Bocah An-Naafi Malang Jawa Timur berdasarkan observasi yang peneliti lakukan sebagai berikut. Pertama, bahan dan alat: pecahan genting atau koin dan kapur atau alat yang bisa buat garis. Kedua, variasi bahan dan alat: Beling, batu granit, dan uang receh.

Cara pelaksanaan permainan tradisional engklek bentuk menara ini adalah sebagai berikut. Pertama, pada pelaksanaan permainan tradisional angklek anak-anak dianjurkan terlebuh dahulu melakukan hompimpa untuk mengetahui seorang pemain yang akan duluan bermain. Kedua, permainan dimulai dengan melompati kotak no.1 atau disebut undak-undakan, kemudian setelah melompati naik ke kotak berikutnya atau tangga 2,3 yaitu dengan mengangkat satu kaki yaitu kaki kanan. Ketiga, pemain melanjutkan permainan dengan menggunakan kedua kaki membuka kedua kaki kemudian diletakkan pada kotak ke 4 dan ke 5. Keempat, kemudian melanjutkan dengan mengangkat satu kaki kiri menuju kotak 6 setelah itu kotak 8 dan 8 sama seperti pada kotak 4 dan 5. Kelima, setelah itu pemain membalikkan badan lalu kembali ke bawah dengan langkah seperti di atas, namun setelah sampai pada kotak No. 2 pemain dapat berhenti sebentar untuk mengambil beling yang telah dilempar sebelumya. Keenam, setelah mengambil beling kotak yang ditempati beling tersebut harus diinjak oleh pemain. Ketujuh, permainan dilanjutkan dengan melempar pada kotak nomor 2 dan melakukan permainan seperti yang dijelaskan sebelumnya. Saat melempar beling harus berurutan sesuai dengan nomor yang ada di kotak. Kedelapan, setelah sampai pada kotak ke 8 pemain melemparkan beling ke gunung. Lalu pemain mengambil beling itu dengan cara yang sama yaitu melompati sesuai dengan gambar desain tersebut, lalu berjalan ke bawah lagi. Kesembilan, kemudian pemain melemparkan keluar beling yaitu ke atas gunung. Kesepuluh, pemain mengambil beling tersebut dengan cara melompat seperti yang dilakukan sebelumnya di atas dan ketika No. 8 dan 8 pemain melompat keluar dan menginjak kembali beling tersebut sebelum mengambil. Kesebelas, kemudian pemain dapat mengambil beling tersebut sambil menaruh beling itu di atas punggung tangan boleh diontang anting, boleh tidak. Berjalan lagi kebawah dan menginjak beling tersebut sebelum mengambilnya. Keduabelas, permainan dilanjutkan dengan melakukan uncal atau membuat omah (rumah) dengan cara posisi badan membelakangi kotak atau gambar yang telah dibuat dan beling ditaruh atau dipegang pada genggaman tangan dengan kuat kemudian dilemparkan kearah belakang. Jika tepat pada kotak dan tidak terkena garis maka pemain berhak membuat rumah pada urutan yang pertama dan rumah yang selanjutnya sesuai dengan urutan. Pembuatan rumah ini sampai pada gunung dan jika ada bantuan kotakan bisa juga dipakai sesuai dengan kesepakatan pemain.

Kegiatan observasi dilaksanakan dari tanggal 13 Januari-28 Februari 2020 dan berlansung setiap hari Senin sampai Kamis jam 10.30 - 11.15 WIB pada saat permainan tradisional Engklek dan Petak Umpet sedang dilakukan oleh anak di PAUD tersebut dengan menggunakan pedoman observasi yang telah disediakan. Adapun hal yang akan di observasi pada anak adalah tentang karakter, yaitu (1) religius, (2) nasionalis, (3) gotong royong, (4) integritas, dan (5) mandiri. Permainan tradisional Engklek dan Petak Umpet pada anak harus lebih dikondisikan dengan usia dan tahap tumbuh perkembangan anak masingmasing serta dengan mencakup semua aspek perkembangannya yaitu dengan beberapa diantaranya aspek sosial emosional, aspek kognitif, aspek bahasa, aspek fisik motorik, dan aspek seni. Ketika proses permainan tradisional sedang berlangsung yang dilakukan oleh anak-anak maka guru PAUD melakukan bimbingan dan melakukan penilaian terhadap masing-masing anak. Melakukan observasi tersebut guru mencatat perkembangan dan perubahan karakter anak pada saat bermain permainan tradisional Engklek dan Petak Umpet.

Permainan tradisional Engklek dan Petak Umpet diawali dengan berdo'a bersama tujuan dari sebelum dan sesudah melakukan kegiatan adalah untuk menanamkan nilai religius agar anak senantiasa terus mengingat dan lebih dekat kepada Allah SWT ataupun sang pencipta. Dilanjutkan dengan melakukan hompimpa untuk permainan petak umpet maupun permainan angklek, seperti yang tampak pada gambar 1. 


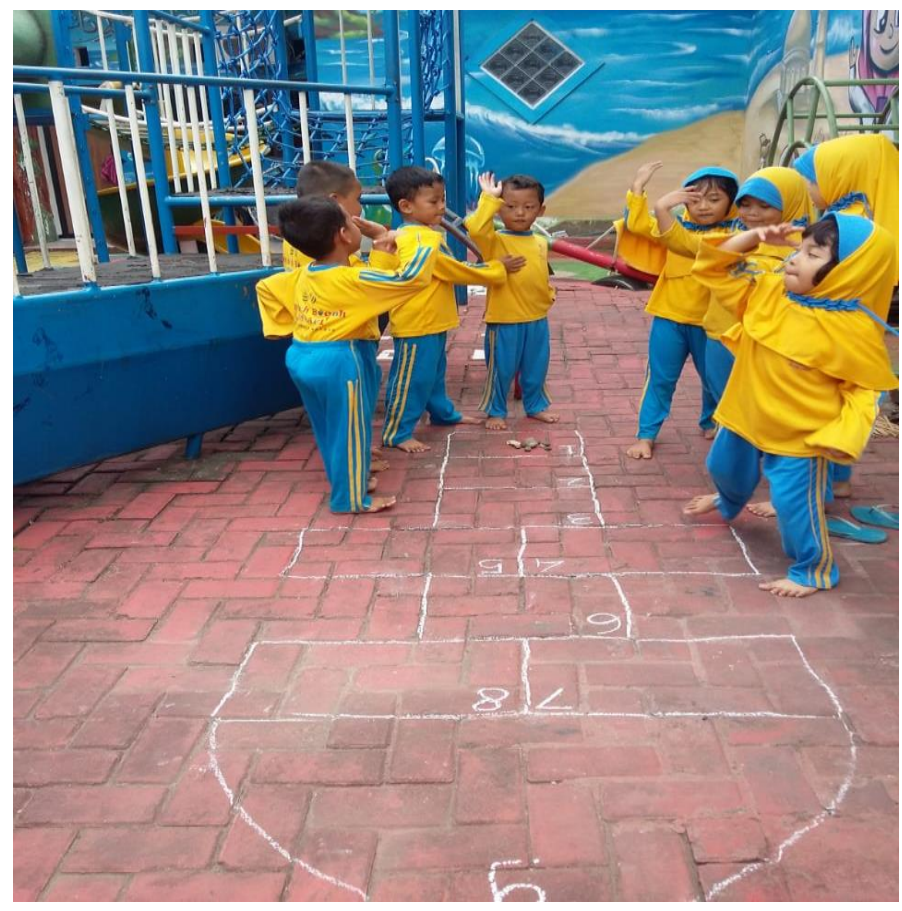

\section{Gambar 1. Anak-Anak Sedang Melakukan Hompimpa Sebelum Bermain Permainan Tradisional Engklek}

Perubahan sikap ataupun karakter pada anak dapat dilihat setelah melaksanakan permainan tradisional Engklek dan Petak Umpet antara lain: jika sebelumnya anak sulit berbaris, tidak saling tolong menolong, mendorong teman yang berada disampingnya, tidak menghargai permainan yang dimainkan, dan tidak mau mendengarkan guru, namun setelah satu bulan setengah peneliti mengamati anak yang sedang melakukan permainan tradisional dan kebiasaan yang telah dilakukan anak mengalami perubahan yang lebih baik dimana dalam karakter religius anak selalu berdoa ketika mau makan jajan yang dibawanya dari rumah, karakter mandiri yang terlihat dimana anak mandiri mengambil sendiri apa keinginannya tanpa harus menyuruh teman ataupun guru lainnya, karakter tanggungjawab dimana anak bertanggungjawab saat anak melakukan kesalahan dan mengakui kesalahannya, karakter gotong royong dimana anak saling membereskan bersama-sama alat-alat yang digunakan setelah selesai bermain, dan karakter nasionalis dimana anak sudah mulai senang akan permainan tradisional Engklek dan Petak Umpet yang dimainkan anak-anak yang lainnya.

\section{PEMBAHASAN}

Penerapan pelaksanaan permainan tradisional Engklek dan Petak Umpet untuk menanamkan nilai karakter anak usia dini dikemas dengan karakteristik anak dan pelaksanaannya juga berpedoman pada kurikulum PAUD tahun 2013 sehingga sesuai pada tahap perkembangan anak untuk selanjutnya. Pelaksanaan permainan tradisional Engklek dan Petak Umpet untuk membentuk karakter anak usia dini merupakan kegiatan yang dilaksanakan secara kurikuler dan rutin setiap hari Senin sampai Kamis yang melibatkan anak dan Guru PAUD. Permainan tradisional Engklek dan Petak Umpet dilaksanakan untuk membentuk nilai karakter anak antara lain, religius, tanggung jawab, nasionalis, gotong royong, dan mandiri. Sebagaimana yang disampaikan oleh (Nur, 2013) dimana permainan tradisional anak dapat merangsang anak dalam mengembangkan rasa kerjasama, membantu sesama, anak dapat mengontrol diri sendiri, rasa empati terhadap sesama, menaati aturan, dan menghargai orang lain dengan melakukan permainan tradisional Engklek dan Petak Umpet. Selain itu, (Saputra \& Ekawati, 2017) juga menyatakan bahwa permainan tradisional juga dapat menstimulus kecerdasan pada anak baik itu kecerdasan spiritural, kemampuan memahami diri sendiri, kecerdasan interpersonal dan juga kecerdasana akan keindahan alam yang semua itu dapat dilihat pada anak saat melakukan permainan tradisional. Sebagaimana juga (Siregar \& Lestari, 2018) menyatakan bahwa permainan tradisional juga dapat merangsang kemampuan anak dalam matematika terutama berhitung, menambah, mengurang, dan juga membagi ketika melakukan permainan tradisional.

Permainan tradisional Engklek dan Petak Umpet merupakan suatu cara yang efektif untuk menanakan nilai karakter anak usia dini. Pernyataan tersebut dikarenakan perkembangan anak pada rentang usia empat sampai enam tahun berlangsung dengan alamiah sehingga perlu diberikan rangsangan untuk mengembangkan potensi sejak dini, yaitu melalui permainan tradisional Engklek dan Petak Umpet. Permainan tradisional dapat membentuk interaksi sosial pada anak bersama dengan temannya. Sebagaimana hal serupa juga dikatakan oleh (Nugraha, Handoyo, \& Sulistyorini, 2018) yang menyatakan bahwa permainan tradisional dapat meningkatkan keterampilan sosial pada anak dan menjadikan anak lebih terampil dalam bersosial. 
Hasil penerapan permainan tradisional Engklek dan Petak Umpet dilakukan dengan pembiasaan oleh guru PAUD dengan membentuk karakter anak usia dini melalui permainan yang menarik dan bentuk yang berbeda pada tahap perkembangan anak sehingga untuk memudahkan guru dalam membentuk karakter pada anak. Kegiatan permainan tradisional Engklek dan Petak Umpet tidak jauh dari pembelajaran kurikulum PAUD yang mengedepankan karakter anak kelak mereka dewasa. Perubahan karakter pada anak setelah melakukan permainan tradisional Engklek dan Petak Umpet dapat dilihat setelah mengikuti kegiatan permainan yang dilakukan oleh anak-anak selama kurang lebih dua bulan setengah. Perubahan karakter anak sebelum dan sesudah melaksanakan permainan tradisional Engklek dan Petak Umpet berdasarkan penilaian observasi dan penilaian dari guru PAUD dapat dilihat pada tabel 1.

Tabel 1. Perubahan Karakter Anak Sebelum dan Sesudah Melakukan Kegiatan Permainan Tradisional

\begin{tabular}{|c|c|c|}
\hline Karakter & Sebelum melakukan permainan tradisional & Setelah melakukan permainan tradisional \\
\hline Religius & $\begin{array}{l}\text { Selalu menggangu teman saat berdo'a bersama } \\
\text { Ketika makan langsung melahap makanan dan lupa akan } \\
\text { berdoa } \\
\text { Ketika berdoa lafal yang diucapkan oleh anak asal-asalan }\end{array}$ & $\begin{array}{l}\text { Anak diam dan berdoa dengan baik dan tidak menganggu } \\
\text { temannya lagi } \\
\text { Ketika makan anak sudah terbiasa berdo'a terlebih dahulu } \\
\text { Anak melakukan doa dengan lafal yang baik dan benar }\end{array}$ \\
\hline Mandiri & $\begin{array}{l}\text { Merapikan mainan yang dimainkan masih dibantu } \\
\text { Mengambil makanan didalam tas masih ingin dibantu }\end{array}$ & $\begin{array}{l}\text { Merapikan mainan sendiri } \\
\text { Sudah bisa mengambil makanan sendiri }\end{array}$ \\
\hline Tanggungjawab & $\begin{array}{l}\text { Tidak mengembalikan mainan pada tempat yang sudah } \\
\text { disediakan } \\
\text { Tidak mau meminta maaf salah melakukan kesalahan } \\
\text { Membuang sampah sembarangan }\end{array}$ & $\begin{array}{l}\text { Anak sudah terbiasa mengembalikan mainan pada } \\
\text { tempatnya } \\
\text { Anak meminta maaf saat melakukan kesalahan } \\
\text { Anak sudah terbiasa membuang sampah pada tempatnya }\end{array}$ \\
\hline Nasionalis & $\begin{array}{l}\text { Tidak menyukai permainan tradisional yang sedang } \\
\text { dimainkan }\end{array}$ & $\begin{array}{l}\text { Anak sudah suka dengan permainan tradisional yang } \\
\text { dimainkan dan mulai senang dengan permainannya }\end{array}$ \\
\hline Gotong royong & $\begin{array}{l}\text { Tidak menyukai kerjasama untuk membantu teman } \\
\text { lainnya } \\
\text { Tidak mempedulikan teman yang meminta bantuan }\end{array}$ & $\begin{array}{l}\text { Anak sudah saling kerjasama sama teman-temannya } \\
\text { Anak membantu teman jika butuh bantuan }\end{array}$ \\
\hline
\end{tabular}

\section{SIMPULAN}

Permainan tradisional Engklek dan Petak Umpet adalah salah satu permainan untuk lebih mendewasakan anak pada lingkungan masyarakat. Sehingga begitu banyak manfaat yang dapat di dapatkan ketika anak bermain permainan tradisional yang mengandung nilai-nilai positif. Melalui kegiatan permainan tradisional yang telah ada, anak-anak akan mengalami proses pendewasaan secara alamiah. Hal tersebutlah yang sangat penting dalam pembentukan karakter anak. Penerapan maupun pelaksanaan permainan tradisional Engklek dan Petak Umpet adalah metode yang baik untuk membentuk karakter anak yang dapat dilakukan mulai sedini mungkin. Hasil dari permainan tradisional Engklek dan Petak Umpet dapat dilihat setelah anak melaksanakan permainan tradisional Engklek dan Petak Umpet selama kurang lebih dua bulan di PAUD Omah Bocah AnNa'afi Malang dimana karakter ada religius, nasionalis, integritas, gotong royong dan mandiri semkain meningkat dalam hal karakter yang positif dan karakter yang dapat membentuk perilaku yang baik pada kehidupan anak sehari-hari baik di sekolah maupun di luar sekolah.

Adapun saran yang dapat disampaikan oleh peneliti, ditujukan untuk kepala sekolah, guru, dan orangtua. Pertama, kepala PAUD Omah Bocah An-Na'afi Malang Jawa Timur disarankan agar dapat mensosialisasikan permainan tradisional Engklek dan Petak Umpet untuk membentuk karakter anak usia dini pada lembaga PAUD lainnya dengan melibatkan berbagai pihak terkait agar permainan tradisional lebih terkenal dan senantiasa anak lebih menyukainya. Kedua, guru PAUD Omah Bocah An-Na'afi Malang Jawa Timur disarankan agar penerapan permainan tradisional Engklek dan Petak Umpet untuk membentuk karakter anak usia dini seharusnya dapat dilaksanakan lebih bervariasi dalam alat-alat yang digunakan saat bermain agar anak lebih senang. Ketiga, orangtua disarankan agar lebih membiasakan anak bermain permainan tradisional Engklek dan Petak Umpet di rumah maupun di lingkungan ia bermain untu membentuk karakternya yang baik karena sangat bermanfaat kelak ia dewasa nanti.

\section{DAFTAR RUJUKAN}

Akbar, S. (2015). Pendidikan Karakter Best Practices. Malang: Universitas Negeri Malang.

Aghlara, L., \& Tamjid, N. H. (2011). The Effect of Digital Games on Iranian Children's Vocabulary Retention in Foreign Language Acquisition. Procedia - Social and Behavioral Sciences, 29, 552-560. https://doi.org/10.1016/j.sbspro.2011.11.275

Ambaryani, N., Yustinus, N., \& Sujana, Y. (2014). Efektivitas Permainan Tradisional terhadap Keterampilan Sosial Anak Kelompok B TK se-gugus IV Kecamatan Banjarsari Surakarta Tahun Ajaran 2013/2014. Skripsi tidak diterbitkan. Universitas Sebelas Maret, Surakarta.

Anggita, G. M. (2019). Eksistensi Permainan Tradisional sebagai Warisan Budaya Bangsa. JOSSAE : Journal of Sport Science and Education, 3(2), 55. https://doi.org/10.26740/jossae.v3n2.p55-59 
Eichberg, H. (2005). Traditional Games : A Joker in Modern Development . Some Experiences from Nordic Countries and Nordic-African Exchange. International Journal of Eastern Sports \& Physical Education, 4(1), 1-14.

Gunawan, H. (2017). Pendidikan Karakter Konsep dan Implementasinya. Bandung: Alfabeta.Lusiana, E. (2012). Membangun Pemahaman Karakter Kejujuran melalui Permainan Tradisional pada Anak Usia Dini di Kota Pati. Skripsi tidak diterbitkan. Universitas Negeri Semarang, Semarang.

Iswinarti. (2017). Permainan Tradisional Prosedur dan Analisis Manfaat Psikologis. Malang: Universitas Muhammadiyah Malang.

Merpina., Marmawi., \& Yuline. (2014). Menanamkan Kejujuran melalui Permainan Congklak pada Anak Usia 5-6 Tahun. Jurnal Pendidikan dan Pembelajaran Khatulistiwa, 3(3), 1-10.

Moleong, L. (2011). Metodologi Penelitian Kualitatif. Bandung: Remaja Rosdakarya.

Nugraha, Y. A., Handoyo, E., \& Sulistyorini, S. (2018). Traditional Game on The Social Skill of Students in The Social Science Learning of Elementary School. Journal of Primary Education, 7(2), 220-227.

Nur, H. (2013). Membangun Karakter Anak Melalui Permainan Anak Tradisional. Jurnal Pendidikan Karakter, 3(1), 87-94.

Rahmawati, R. P., \& Harsono, A. D. (2018). Strengthening Character Education through Traditional Cultural Heritage. Proceeding International Seminar on Education Innovation Issues and Challenges in Education for Education Sustainability Universitas Sarjanawiyata Tamansiswa (August), 28-35.

Rochmani, I. (2016). Permainan Tradisional Engklek Berpengaruh terhadap Perkembangan Motorik Anak. Skripsi tidak diterbitkan. Universitas Muhammadiyah Surakarta, Surakarta.

Saputra, N. E., \& Ekawati, Y. N. (2017). Meningkatkan Kemampuan Dasar Anak Tradisional Games in Improving Children's Basic Abilities. Jurnal Psikologi Jambi, 2(2), 48-53.

Saputra, S. Y. (2017). Permainan Tradisional vs Permainan Modern dalam Penanaman Nilai Karakter di Sekolah Dasar. Elementary School Education Journal, 1(1), 1-7.

Sibarani, D. F. (2018). Permainan Tradisional terhadap Pembentukan Karakter Anak (Studi Etnografi di Desa Sikeben, Kecamatan Sibolangit, Kabupaten Deli Serdang). Skripsi tidak diterbitkan. Universitas Sumatera Utara.

Siregar, N., \& Lestari, W. (2018). Peranan Permainan Tradisional dalam Mengembangkan Kemampuan Matematika Anak Usia Sekolah Dasar. Jurnal Mercumatika : Jurnal Penelitian Matematika dan Pendidikan Matematika, 2(2), 1-7. https://doi.org/10.26486/jm.v2i1.427

Sugiyono. (2017). Metode Penelitian Kuantitaif, Kualitatif dan $R \& D$. Bandung: Alfabeta.

Suhono, S., \& Sari, Y. A. (2017). Retrofitting Javanese Traditional Games as Indonesia Culture Identity: Providing English Vocabulary. Jurnal Iqra', 2(1), 213. https://doi.org/10.25217/ji.v2i1.123

Suruh, D. I. K. (2013). Efektivitas Permainan Tradisional Jawa Dalam Meningkatkan Penyesuaian Sosial Pada Anak Usia 4-5 Tahun di Kecamatan Suruh. Indonesian Journal of Early Childhood Education Studies, 2(1), 8-16. https://doi.org/10.15294/ijeces.v2i2.9235

Widodo, P., \& Lumintuarso, R. (2017). Pengembangan Model Permainan Tradisional untuk Membangun Karakter pada Siswa SD Kelas Atas. Jurnal Keolahragaan, 5(2), 183-193. https://doi.org/10.21831/jk.v5i2.7215 